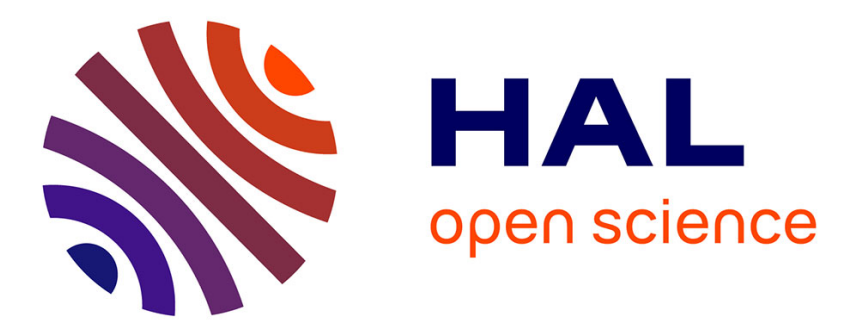

\title{
IGF-1 receptor regulates lifespan and resistance to oxidative stress in mice
}

Martin Holzenberger, Joëlle Dupont, Bertrand Ducos, Patricia Leneuve, Alain Geloen, Patrick C. Even, Pascale Cervera, Yves Le Bouc

\section{- To cite this version:}

Martin Holzenberger, Joëlle Dupont, Bertrand Ducos, Patricia Leneuve, Alain Geloen, et al.. IGF-1 receptor regulates lifespan and resistance to oxidative stress in mice. Nature, 2003, 421 (6919), pp.182 - 187. 10.1038/nature01298. hal-01939325

\section{HAL Id: hal-01939325 \\ https://hal.sorbonne-universite.fr/hal-01939325}

Submitted on 29 Nov 2018

HAL is a multi-disciplinary open access archive for the deposit and dissemination of scientific research documents, whether they are published or not. The documents may come from teaching and research institutions in France or abroad, or from public or private research centers.
L'archive ouverte pluridisciplinaire HAL, est destinée au dépôt et à la diffusion de documents scientifiques de niveau recherche, publiés ou non, émanant des établissements d'enseignement et de recherche français ou étrangers, des laboratoires publics ou privés. 


\section{IGF-1 receptor regulates lifespan and resistance to oxidative stress in mice}

Martin Holzenberger ${ }^{*}$, Joëlle Dupont ${ }^{\dagger}$, Bertrand Ducos ${ }^{*}$, Patricia Leneuve ${ }^{*}$, Alain

Géloën ${ }^{\ddagger}$ Patrick C. Even ${ }^{\S}$, Pascale Cervera" ${ }^{\|}$Y Yves Le Bouc*

*INSERM U515, Hôpital Saint-Antoine, 75571 Paris 12, France

${ }^{\dagger}$ INRA, 37380 Nouzilly, France

"INSERM U352, INSA, 69621 Villeurbanne, France

${ }^{\S}$ INRA, INA P-G, 75231 Paris 5, France

"Service d'Anatomie et de Cytologie Pathologiques, Hôpital Saint-Antoine, 75571 Paris 12, France

InR and DAF-2 have been shown to regulate longevity in insects and worms, respectively. These evolutionarily related tyrosine kinase receptors are structurally similar to both the insulin receptor (IR) and insulin-like growth factor type 1 receptor (IGF-1R) of mammals. To investigate whether IGF-1R also controls longevity in mammals, we inactivated the IGF-1R gene in the mouse. We used heterozygous knockout mice (IGF-1 ${ }^{+/}$) because null mutants were not viable. We demonstrated that IGF-1 $\mathrm{R}^{+/-}$mice had half the normal number of receptors and were healthy. IGF-1 $\mathrm{R}^{+/}$mutants lived a mean of $26 \%$ longer than their wild-type littermates $(P<0.02)$. When evaluated separately, female mutants lived $33 \%(P<$ 0.001) longer than wild-type females, whereas the increase in longevity of male mutants (+16\%) was not significant. Long-lived IGF-1R ${ }^{+/-}$mice did not develop dwarfism, their energy metabolism was normal, and their nutrient uptake, physical activity, fertility and reproduction were unaffected. IGF-1R ${ }^{+/-}$mutants showed greater resistance in vivo to oxidative stress, a major determinant of 
ageing. These results indicate that the IGF-1 receptor may be a key regulator of mammalian, and possibly of human, lifespan.

Genes regulating lifespan were recently identified in non-vertebrates and shown to encode proteins of the CLK family or of the insulin/insulin-like signalling (IIS) pathways $^{1-3}$. The IIS genes identified included those encoding DAF-2 (Caenorhabditis elegans) and InR (Drosophila melanogaster). Partial inactivation of these genes significantly increased lifespan in worms $s^{4,5}$ and insects ${ }^{6,7}$ respectively. Null mutations of insect insulin-receptor substrate CHICO, acting downstream from InR, also extended lifespan ${ }^{8}$. Most long-lived $d a f-2$ and Inr mutants developed dwarfism and hypofertility, but some Inr mutants displayed normal fertility and growth. This suggests that longevity may be regulated independently of body size and reproduction ${ }^{7,8}$. DAF-2 and InR are structural homologues of a family of vertebrate tyrosine kinase receptors that includes the insulin receptor (IR) and the insulin-like growth factor type 1 receptor (IGF-1R). In vertebrates, IR regulates energy metabolism ${ }^{9}$ whereas IGF-1R promotes growth ${ }^{10}$. IGF$1 \mathrm{R}$ is activated by its ligand IGF-I, which is secreted in response to growth hormone (GH). It is currently unclear whether IR or IGF-1R, or both, has taken over responsibility for lifespan regulation in vertebrates ${ }^{3,8}$. The phenotypes of long-lived spontaneous mouse mutants studied to date indicate a probable link between longevity and growth. The long-lived Prop $1^{\mathrm{df} / \mathrm{df}}$ (Ames dwarf), and the Pit $1^{\mathrm{dw} / \mathrm{dw}}$ (Snell dwarf) mutants ${ }^{11,12}$ display impaired pituitary gland development and very low levels of pituitary hormones, including GH. These mutants are sterile dwarfs. The recent targeted inactivation of the GH receptor itself, which strongly decreases circulating IGF-I and impairs growth and development, also increases lifespan ${ }^{13}$. Similarly, caloric restriction, the only efficient treatment known to increase mammalian lifespan, invariably reduces circulating IGF-I levels, and, if begun in juveniles, also engenders dwarfism. These findings led us to investigate whether mammalian lifespan is regulated by IGF-1R. 
We inactivated the IGF-1R gene by homologous recombination, using the Crelox strategy to delete the essential exon 3 of the gene ${ }^{14,15}$ (Fig. 1a). We found that nullizygous (IGF-1R ${ }^{-/}$) newborns died at birth, as previously described by the group of Efstratiadis ${ }^{16}$, in a study using classical insertional mutagenesis. Our IGF-1R ${ }^{+/-}$mutant transmitted the null allele in Mendelian ratio $(52 \%, \mathrm{n}=241)$. Wild-type and IGF-1R ${ }^{-}$ transcripts were present (Fig. 1b). However, as IGF-1R' transcripts cannot be translated into functional protein ${ }^{15}$, IGF-I receptor levels in IGF-1 $\mathrm{R}^{+/-}$mice were half those in wild type IGF-1R $\mathrm{R}^{+/+}$mice (Fig. 1c). Weight at birth and during the first three weeks of growth were nevertheless normal (Fig. 1d). Only after natural weaning (around day 20) did IGF-1R ${ }^{+/-}$males develop a modest, $8 \%$ growth deficit with respect to their IGF$1 \mathrm{R}^{+/+}$littermates $(23.1 \pm 0.7 \mathrm{~g}$ vs. $25.1 \pm 0.7 \mathrm{~g}$ at age 7 weeks, $P<0.05)$, whereas the growth deficit did not exceed $6 \%$ in females $(19.5 \pm 0.6 \mathrm{~g}$ vs. $20.7 \pm 0.5 \mathrm{~g}$ at 7 weeks, NS). These modest weight differences affected all tissues to similar degrees, persisted throughout life (data not shown), and resembled the growth pattern observed in previous models of partial IGF-1R inactivation ${ }^{15}$. Thus, the bi-allelically expressed mouse IGF$1 \mathrm{R}$ gene is in fact hetero-insufficient.

Fed ad libitum on standard diet and maintained in regular housing until natural death, mice with only one functional IGF-1R allele significantly outlived their wild-type littermates (Fig. 2). IGF-1R $\mathrm{R}^{+/-}$mice lived a mean of $26 \%$ longer than IGF-1R $\mathrm{R}^{+/+}$controls $(P<0.02 ;$ Cox's test $)$. If the sexes were evaluated separately, mutant females were found to live $33 \%$ longer than wild-type females $(P<0.001)$ whereas mutant males lived only $15.9 \%$ longer than control males (NS). On average, IGF-1 $\mathrm{R}^{+/}$females outlived IGF-1 $\mathrm{R}^{+/-}$males, whereas the opposite is normally the case in wild-type populations of 129 genetic background ${ }^{17}$ (Fig. 2). Thus, in IGF-1R ${ }^{+/-}$mice, the degree to which lifespan was extended depended on sex, as has been described for Drosophila mutants with impaired insulin-like signalling ${ }^{6,8}$. Our ageing cohorts had a 5\% tumour incidence, unrelated to genotype and consistent with the low (7\%) general tumour 
incidence of mice with 129 background $^{18,19}$. Necropsy revealed a number of different diseases, consistent with the results of previous studies, showing that mice with this background do not develop specific age-related diseases ${ }^{19}$. We did not observe accidental deaths, although some of the sporadic mortality of younger males may have been consequences of fights for dominance.

Blood parameters (see Methods) were normal. However, serum IGF-I levels were up-regulated in adult IGF-1R ${ }^{+/-}$mice (males: $795 \pm 64$ vs. $625 \pm 30 \mathrm{ng} \mathrm{ml}^{-1}, P<$ 0.01 ; females: $716 \pm 39$ vs. $516 \pm 14 \mathrm{ng} \mathrm{ml}^{-1}, P<0.001 ; \mathrm{n}=8-10$ per group) and may reflect an endocrine response to the reduced availability of IGF-1 $\mathrm{R}^{15}$. Blood glucose levels in overnight fasted animals were unaffected. In fed animals, however, IGF-1 $\mathrm{R}^{+/-}$ males tended to have higher $(+12 \%)$, and IGF-1 $\mathrm{R}^{+/-}$females to have lower $(-4.4 \%)$ blood glucose levels than the controls. Non-fasting insulin levels were nevertheless normal (males: $1.65 \pm 0.12$ vs. $1.40 \pm 0.14 \mathrm{ng} \mathrm{ml}^{-1}$; females: $1.58 \pm 0.25$ vs. $1.90 \pm 0.25$ $\mathrm{ng} \mathrm{ml}{ }^{-1} ; \mathrm{n}=8-10$ per group). We then tested glucose tolerance in overnight fasted animals (Fig. 3a,b), and found that IGF-1R ${ }^{+/-}$males had a significantly stronger glucose response than controls $(P<0.001)$. In IGF-1R $\mathrm{R}^{+/-}$females, the response was slightly weaker than in wild-type females $(P<0.05)$. It remains unclear whether this hyperglycaemic effect in IGF-1R $\mathrm{R}^{+/-}$males is related to the reportedly compromised $\beta$ cell mass in these mice ${ }^{20}$.

As metabolism may play an important role in ageing, we explored energy expenditure in IGF-1 $\mathrm{R}^{+/-}$mice. Body temperature, indicative of metabolic activity, and reported to be low in long-lived Ames dwarf mice ${ }^{21}$, was unaffected in IGF-1 $\mathrm{R}^{+/-}$mice: skin surface temperature was $36.1 \pm 0.1^{\circ} \mathrm{C}$ for all 4 groups $(\mathrm{n}=9-14$ per group) and rectum temperature was $37.4 \pm 0.2$ vs. $37.5 \pm 0.2{ }^{\circ} \mathrm{C}$ in males, and $37.7 \pm 0.2$ vs. $37.9 \pm$ $0.2^{\circ} \mathrm{C}$ in females (NS). We analysed physical activity, using a photoelectric actimeter, and found identical circadian profiles for IGF-1R ${ }^{+/-}$and IGF- $1 \mathrm{R}^{+/+}$mice (data not 
shown). Furthermore, as caloric restriction is known to extend rodent lifespan, we investigated the possibility that IGF-1 $\mathrm{R}^{+/-}$mice autorestricted their food intake. We measured short-term (1-3 days) and long-term (90 days) food intake in adults. However, we observed only marginal differences between IGF-1R $\mathrm{R}^{+/-}$and IGF-1 $\mathrm{R}^{+/+}$mice, mean food intake (in $\mathrm{g} \mathrm{d}^{-1} \mathrm{~kg}^{-1}$ body weight) being $190 \pm 2$ vs. $204 \pm 4$ (NS) in males and 148 \pm 4 vs. $144 \pm 2$ (NS) in females, and mean water intake (in $\mathrm{ml} \mathrm{d}^{-1} \mathrm{~kg}^{-1}$ body weight) being $249 \pm 7$ vs. $255 \pm 29$ (NS) in males, and $178 \pm 4$ vs. $166 \pm 3$ (NS) in females.

As mice may utilise nutrients with variable efficiency, we determined their metabolic rates (MR). However, we obtained similar mean MR in fed animals over 24 hours (males: $332.8 \pm 6.7$ vs. $336.0 \pm 8.4 \mathrm{~J} \mathrm{~min}^{-1} \mathrm{~kg}^{-0.67}$; females: $351.9 \pm 6.0$ vs. $337.9 \pm$ $7.0 \mathrm{~J} \mathrm{~min}^{-1} \mathrm{~kg}^{-0.67}$; NS, $\mathrm{n}=11-12$ per group) (Fig. 3c). The resting MR was also similar between mutants and controls. As the difference between resting and 24-hour MR depends mainly on physical activity, these results are consistent with the observed identical activity profiles. Even basal MR, measured in the fasted state, did not differ between mutants and controls (males: $133.2 \pm 5.3$ vs. $132.0 \pm 4.7$; females: $135.8 \pm 9.4$ vs. $\left.140.9 \pm 6.6 \mathrm{~J} \mathrm{~min}^{-1} \mathrm{~kg}^{-0.67}\right)$.

Long-lived C. elegans daf-2 mutants and long-lived dwarf mice display changes in fertility. We therefore monitored fertility and reproduction in $\mathrm{IGF} 1 \mathrm{R}^{+/}$females from puberty to the age of 13 months. IGF-1R ${ }^{+/-}$females became fertile at $5.2 \pm 0.1$ weeks whereas IGF-1R $\mathrm{R}^{+/+}$females became fertile at $5.6 \pm 0.3$ weeks $(5.8 \pm 0.1$ vs. $6.2 \pm 0.3$ in males; $\mathrm{n}=7$ - 11 per group). Although these differences were not significant, IGF-1R $\mathrm{R}^{+/-}$ mice became fertile, on average, 3 days earlier than controls. This provides evidence that IGF-1R insufficiency does not delay sexual maturation, in contrast to the growth hormone receptor and binding protein $(\mathrm{GHR} / \mathrm{BP})$ knockout $^{13}$. The litter size of young IGF-1R ${ }^{+/-}$females was $6.3 \pm 0.5(\mathrm{n}=7$ litters), which is not different from wild-type $129 / \mathrm{Sv}$ females $(6.4 \pm 0.2$ life newborns; $n=120$ litters $)$. We analysed the age-related 
decline in female fertility, determining frequency of pregnancies, number of live newborns, mating behaviour, oestrus cycle length and ovarian capacity to maintain pseudogestation (Fig. 4a-d). As expected, fertility decreased drastically with age, but IGF-1 $\mathrm{R}^{+/-}$females and their controls displayed indistinguishable profiles.

Oxidative stress clearly is a major cause of ageing ${ }^{22}$, and mouse and fly mutants with enhanced resistance to oxidative stress are long-lived ${ }^{23,24}$. We therefore subjected adult mice to oxidative stress by injection of paraquat, a herbicide that induces formation of reactive oxygen species. IGF- $1 \mathrm{R}^{+/-}$mutants resisted this challenge significantly longer than controls (Fig. 4e). This increase in stress resistance seemed to be more pronounced in female than in male mutants (Fig. 4e, inset). To further substantiate these results, we induced oxidative damage in cultured mouse embryo fibroblasts (MEF) by low concentrations of $\mathrm{H}_{2} \mathrm{O}_{2}$, and found that the proportion of surviving cells was significantly higher in IGF-1R ${ }^{+/-}$than in control MEF after 24 and 72 hour treatments ( 24 h: $94 \% \pm 3$ vs $82 \% \pm 3, P<0.02 ; 72$ h: $88 \% \pm 3$ vs $68 \% \pm 2, P<$ $0.001)$.

Mutations of Drosophila IRS homologue $\mathrm{CHICO}^{8}$ and of other proteins acting downstream of IGF-1R, like mouse $\mathrm{p} 66 \mathrm{Shc}^{23}$ and C. elegans PI(3)K (AGE-1) ${ }^{1}$, but also regulation of Forkhead transcription factor daf-16 by Akt, increase lifespan. We therefore investigated how the reduced IGF-1R levels affected intracellular signalling in this model. We derived embryonic fibroblasts from WT, IGF- $1 \mathrm{R}^{+/-}$and ${ }^{-/-}$mice $^{14,15}$, and studied signalling by Western blot. As expected, IGF-1R $\mathrm{R}^{+/-}$cells showed $50 \%$ reduction in IGF-1R levels (Fig. 5a). Immunoprecipitation and Western analysis showed also a marked reduction in IGF-I-induced phosphorylation of IGF-1R and of its substrate IRS1 (Fig. 5b). The phosphorylation of both p52 and p66 isoforms of Shc, another major substrate of IGF-1R, were also reduced by half (Fig. 5b). This is of considerable interest since reduced p66 Shc activation in IGF-1R ${ }^{+/-}$cells could be a mechanism by which 
IGF-I regulates oxidative stress resistance. Shc and IRS-1 bind Grb2 upon phosphorylation and thereby activate the MAP kinase pathway, involved in mitogenic response. We showed that the amounts of Grb2 co-immunoprecipitating with p52 Shc or IRS-1 were reduced to half in IGF-1R ${ }^{+/-}$cells (Fig. 5c). Two important pathways activated by IGF-I are the MAP kinase ERK1/2 and PI(3)K/Akt kinase signalling cascades. Consistently, IGF-I-stimulated phosphorylation of ERK1/2 and Akt was reduced by 40 to $50 \%$ in mutant cells (Fig. $5 \mathrm{~d}$ ). Together, this suggested that IGF-1R hetero-insufficiency downregulates the principal pathways stimulated by IGF-I.

These results show that a general decrease in IGF-1 receptor levels can increase lifespan in a mammalian species. Thus, the genetic link between insulin-like signalling and longevity, originally discovered in non-vertebrates ${ }^{4-6}$, also seems to exist in higher vertebrates. Unlike long-lived mouse mutants with hypopituitarism ${ }^{11,12,26}$ or with complete lack of GHR/BP ${ }^{13}$, long-lived IGF-1R ${ }^{+/-}$mutants, in which receptor levels were only reduced by $50 \%$, did not develop dwarfism or hypofertility. We obtained these results using a 129/Sv genetic background. Preliminary results, however, using an IGF-IR knockdown mutation ${ }^{15}$ on a hybrid background (129/Sv $\times$ C57Bl/6) confirm our findings on lifespan extension (M.H., unpublished data). IGF-1R is involved in the regulation of carbohydrate metabolism and in the pancreatic control of glucose homeostasis ${ }^{27}$. It is therefore not entirely surprising that we found abnormal regulation of blood glucose in IGF-1 $\mathrm{R}^{+/-}$mice. This abnormality affected only males and clearly is a sex-related dimorphism. Reduced glucose tolerance is a symptom of prediabetes, and its potential consequences may have masked an otherwise possibly greater lifeprolonging effect of IGF-1R insufficiency in males. We previously observed other gender-related phenotypic differences in IGF-1R mutants ${ }^{14,15}$ and proposed the interplay of sex-dimorphic pulsatile GH regulation, paracrine secretion and signalling of IGF-I, and androgen/estrogen actions at the target cell level as possible explanations. In addition, similar sex-dimorphism of longevity has been reported in InR mutant 
Drosophila and in long-lived Ames dwarf mice ${ }^{6,12}$. It is tempting to speculate on its physiological significance because major sex-differences in lifespan have been found in numerous species, but clearly many more studies are needed. We thought that the observed variations in blood glucose might have had consequences for energy metabolism and expenditure, and that these mice might present features of caloric restriction. However, we clearly showed that IGF- $1 \mathrm{R}^{+/-}$mice had normal food uptake, physical activity or metabolic rate, excluding metabolic differences as the cause of their longevity. It is, on the contrary, possible that the life-prolonging effects of caloric restriction are due to decreases in circulating IGF-I levels, mimicking the IGF-1R insufficiency produced here.

p66 Shc $\mathrm{Sh}^{-/-}$is the only other targeted mutation in mammals described so far that increases lifespan without inducing major side effects ${ }^{23}$. The p66 isoform of Shc mediates cellular responses to oxidative stress and is, together with IRS-1, a major cytoplasmic signal transduction molecule for IGF-1R. Thus, the resistance of IGF-1 $\mathrm{R}^{+/-}$mice to oxidative stress is of considerable interest, and by showing that the stress-regulating p66 Shc is underphosphorylated in IGF-1R deficiency, we found a plausible mechanism connecting IGF signalling to oxidative stress. Caloric restriction, and decreases in the response to oxidative stress and in insulin-like growth factor signalling all efficiently extend lifespan in mice. However, it is unclear how these mechanisms co-operate and the extent to which they are independent. Data from Drosophila $\mathrm{CHICO}^{1}$ mutants, showing that lifespan is extended much more than could be explained by the modest increase in resistance to oxidative stress ${ }^{8}$, suggested that the two mechanisms operate independently, at least in part, to generate longevity. However, the issue of co-operation and independence of caloric restriction, insulin-like signalling and oxidative stress in lifespan extension remains largely unsolved ${ }^{26,28}$. In the light of very strong oxidative stress resistance phenotypes associated with Caenorhabditis elegans longevity mutations ${ }^{29}$, these aspects merit further study in vertebrates.Our IGF-1R ${ }^{+/-}$mutants 
provide an invaluable tool for future exploration of the mechanisms of lifespan regulation. However, it will also be necessary to try to overproduce IGF antagonists, to administer inhibitors of IGF-1R activation, or to block signal transduction. It has recently been shown that lifespan regulation through insulin-like signals in nonvertebrates probably occurs in a non-cell autonomous fashion ${ }^{30}$. Neurons in the CNS, by sensing the circulating levels of ligand, may play a central role in regulating the ageing of other tissues, via hypothetical endocrine mechanisms. We have begun to investigate this possibility in a mammalian model, using the Cre-lox approach to produce brainspecific IGF-1R knockout mice (BIGFRKO). Homozygous BIGFRKO are microcephalic, sterile, and have a complex neuroendocrine dysfunction, but heterozygous BIGFRKO are healthy and useful for lifespan studies.

\section{Methods}

Mice. This mutant, described elsewhere ${ }^{14}$ and available from www.emma.rm.cnr.it, was maintained in the heterozygous state in 129/Sv genetic background. By mating IGF$1 \mathrm{R}^{+/-}$males with 9- to 12 -week old 129/Sv wild-type females, we generated three cohorts, each composed of heterozygous IGF- $1 \mathrm{R}^{+/-}$and ${ }^{+/+}$(wild type) littermates. Animals lived in conventional conditions: $23^{\circ} \mathrm{C}, 14 / 10$-hour light/dark cycle, standard $\operatorname{diet}(49 \%$ carbohydrates, $24 \%$ proteins, $5 \%$ lipids, $12 \%$ humidity, $10 \%$ minerals and fibre) and water ad libitum. We separated mice from mothers on day 30 and grouped them 6 males or 6 females per cage, both genotypes present in each cage. Mice from

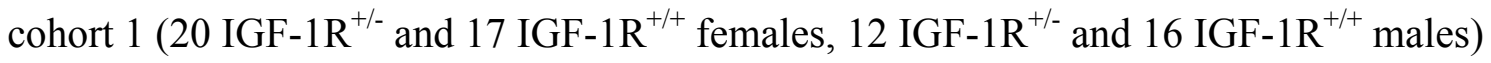
were checked daily but otherwise left undisturbed until they died naturally. Single surviving females were placed in the neighbouring cage, whereas single surviving males received a female for company. We performed necropsy whenever possible, including tumour immunohistochemistry. Four animals were killed when death appeared imminent, to reduce suffering. We drew Kaplan-Meier survival curves using dates of 
birth and death. Cohort $2\left(9 \mathrm{IGF}-1 \mathrm{R}^{+/-}\right.$and $15 \mathrm{IGF}-1 \mathrm{R}^{+/+}$females, $14 \mathrm{IGF}-1 \mathrm{R}^{+/-}$and 11 IGF-1 $\mathrm{R}^{+/+}$males) was used for blood biochemistry and analysis of glucose tolerance, food consumption, fertility and body composition. In cohort 3 (17 IGF-1R ${ }^{+/-}$and 11 IGF-1R ${ }^{+/+}$females, 14 IGF-1R $\mathrm{R}^{+/-}$and 15 IGF-1R $\mathrm{R}^{+/+}$males) we analysed growth, energy expenditure (by indirect calorimetry), blood parameters, glucose tolerance, and finally in vivo resistance to oxidative stress induced by methyl viologen (paraquat) injection. We conducted experiments according to institutional guidelines for care of laboratory animals.

IGF-1 receptor expression. Recombinant human IGF-I (rhIGF-I, for in vitro ligand binding assays, described elsewhere ${ }^{14,15}$ ) and rhdes(1-3)IGF-I (for autoradiography) were labelled with ${ }^{125}$ I (see also supplementary information).

Allele-specific expression assay. Using total RNA from IGF-1R ${ }^{+-}$embryos and a triplex reverse transcriptase (RT)- $\mathrm{PCR}^{27}$, we co-amplified corresponding fragments from the coding region of the mRNA specific for the wild-type and the inactivated receptor allele. The single forward primer 5'-CGCCTGGAAAACTGCACG annealed with exon 2, the first reverse primer 5'-AGCTGCCCAGGCACTCCG annealed with exon 3, and the second reverse primer 5'-GCAGGGGATACAGTACATGTTT spanned the knockout-specific splice junction between exons 2 and 4. RT-PCR products of 518 bp corresponded to the transcript of the knockout allele, and $574 \mathrm{bp}$ products corresponded to wild type. We extracted total RNA from embryo homogenates by RNAXEL and performed One-Step RT-PCR using GeneAmp 2400 cyclers. For the RT reaction, we incubated $30 \mathrm{ng}$ total $\mathrm{RNA}$ at $50^{\circ} \mathrm{C}$ for $30 \mathrm{~min}$ and at $94^{\circ} \mathrm{C}$ for $2 \mathrm{~min}$, followed by 40 PCR cycles, each consisting of $30 \mathrm{~s}$ segments at 94,59 , and $72^{\circ} \mathrm{C}$.

Postnatal growth. To synchronise individual growth, we recomposed 7 litters (cohort 3) on day 1 to yield 8 or 9 pups per mother. We identified newborns with coloured ink and permanently numbered them on day 8 . For 11 weeks we weighed them daily at 4 
p.m. on an electronic balance. Growth curves used sliding means of present weight and weight on the day before and after.

Fertility. We determined the onset of male and female fertility by mating IGF-1 $\mathrm{R}^{+/}$and ${ }^{+/+}$mice from day 30 onwards with fertile wild-type partners (three females per male). The age of delivery and littersize (when testing females) were compared between genotypes. To evaluate the decline in female fertility over time we used three sets of parameters. Measurements started at age 5 months and were repeated 3 or 4 times, at two-month intervals. First, we monitored the oestrus cycle by vaginal smear histology for 18 days. Second, we analysed sexual behaviour and the duration of pseudogestation by mating females for 2 weeks with vasectomised males and recording vaginal plugs. Third, we mated females with fertile males for three weeks and recorded the resulting pregnancies and offspring.

Blood tests. We measured total bilirubin, cholesterol, creatinine, glucose, lactate, total protein, triglycerides, urea and uric acid in 5-month-old mice. Circulating IGF-I was measured using a double-antibody RIA from Diagnostic Systems Laboratories and plasma insulin using the Linco Sensitive Rat Insulin RIA. We tested glucose tolerance in 14 hours overnight fasted animals, by intraperitoneal injection with $2 \mathrm{~g} \mathrm{~kg}^{-1}$ body weight of $25 \%$ D-glucose.Circulating glucose was measured in tail blood at 0, 15, 30, 60 and $120 \mathrm{~min}$, using Lifescan Glucotouch.

Indirect calorimetry. We determined metabolic rate by indirect 24-hour calorimetry (details in supplementary information).

Experiments using mouse embryonic fibroblasts (MEF). We established female MEF from IGF-1R ${ }^{+/+},{ }^{+/}$and ${ }^{-/}$E14 embryos. IGF signalling pathways and in vitro resistance to $\mathrm{H}_{2} \mathrm{O}_{2}$ were studied in early passages of MEF. IGF signalling: We removed serum (10\% FCS) from MEF cultures 16 hours prior to analysis. Cells were stimulated 
with $3 \mathrm{nM}$ rhIGF-I (Genentech) for 10 min prior to analysis, except for detection of phosphorylated Shc (5 min). $\mathrm{H}_{2} \mathrm{O}_{2}$ resistance: We treated MEF with $100 \mu \mathrm{M} \mathrm{H}_{2} \mathrm{O}_{2}$ and determined cell viability after 1-3 days, using trypan blue and a hemocytometer. $\mathrm{N}=6$ for each group, in two independent experiments.

Western blotting. We performed immunoprecipitation and Western blotting as described $^{25}$ (details in supplementary information).

Statistics. For group comparisons, we used Student's $t$-test. Means are expressed \pm standard error of the mean (SEM). Error bars represent the SEM. We determined the significance of survival curves by Cox's test. We used non-parametric Mann-Whitney and $\chi^{2}$ tests where indicated.

1. Guarente, L. \& Kenyon, C. Genetic pathways that regulate ageing in model organisms. Nature 408, 255-262 (2000).

2. Kenyon, C. A conserved regulatory system for aging. Cell 105, 165-168 (2001).

3. Gems, D., \& Partridge, L. Insulin/IGF signalling and ageing: seeing the bigger picture. Curr. Opin. Genet. Dev. 11, 287-292 (2001).

4. Kimura, K. D., Tissenbaum, H. A., Liu, Y. \& Ruvkun, G. Daf-2, an insulin receptorlike gene that regulates longevity and diapause in Caenorhabditis elegans. Science 277, 942-946 (1997).

5. Tissenbaum, H. A. \& Ruvkun, G. An insulin-like signaling pathway affects both longevity and reproduction in Caenorhabditis elegans. Genetics 148, 703-717 (1998).

6. Tatar, M. et al. A mutant Drosophila insulin receptor homolog that extends life-span and impairs neuroendocrine function. Science 292, 107-110 (2001). 
7. Bartke, A. Mutations prolong life in flies; implications for aging in mammals. Trends Endocrinol. Metab. 12, 233-234 (2001).

8. Clancy, D. J. et al. Extension of life-span by loss of CHICO, a Drosophila insulin receptor substrate protein. Science 292, 104-106 (2001).

9. Kulkarni, R. N. et al. Tissue-specific knockout of the insulin receptor in pancreatic beta cells creates an insulin secretory defect similar to that in type 2 diabetes. Cell $\mathbf{9 6}$, 329-339 (1999).

10. Lupu, L., Terwilliger, J. D., Lee, K., Segre, G. V. \& Efstratiadis, A. Roles of growth hormone and insulin-like growth factor 1 in mouse postnatal growth. Dev. Biol. 229, 141-162 (2001).

11. Flurkey, K., Papaconstantinou, J., Miller, R. A. \& Harrison, D. E. Lifespan extension and delayed immune and collagen aging in mutant mice with defects in growth hormone production. Proc. Natl Acad. Sci. USA 98, 6736-6741 (2001).

12. Brown-Borg, H. M., Borg, K. E., Meliska, C. J. \& Bartke, A. Dwarf mice and the ageing process. Nature 384, 33 (1996).

13. Coschigano, K. T., Clemmons, D., Bellushi, L. L. \& Kopchick, J. J. Assessment of growth parameters and life span of GHR/BP gene-disrupted mice. Endocrinology 141, 2608-2613 (2000).

14. Holzenberger, M. et al. Experimental IGF-I receptor deficiency generates a sexually dimorphic pattern of organ-specific growth deficits in mice, affecting fat tissue in particular. Endocrinology 142, 4469-4478 (2001). 
15. Holzenberger, M. et al. A targeted partial invalidation of the insulin-like growth factor I receptor gene in mice causes a postnatal growth deficit. Endocrinology 141, 2557-2566 (2000).

16. Liu, J. P., Baker, J., Perkins, A. S., Robertson, E. J. \& Efstratiadis, A. Mice carrying null mutations of the genes encoding insulin-like growth factor I (Igf-1) and type 1 IGF receptor (Igf1r). Cell 75, 59-72 (1993).

17. Storer, J. B. Longevity and gross pathology at death in 22 inbred mouse strains. $J$. Gerontol. 21, 404-409 (1966).

18. Stevens, L. C. \& Little, C. C. Spontaneous testicular teratomas in an inbred strain of mice. Proc. Natl Acad. Sci. USA 40, 1080-1087 (1954).

19. Smith, G. S., Walford, R. L. \& Mickey, M. R. Lifespan and incidence of cancer and other diseases in selected long-lived inbred mice and their F 1 hybrids. J. Natl Cancer Inst. 50, 1195-1213 (1973).

20. Whithers, D. J. et al. Irs-2 coordinatesIGF-1 receptor-mediated B-cell development and peripheral insulin signalling. Nat. Genet. 23, 32-39 (1999).

21. Hunter, W. S., Croson, W. B., Bartke, A., Gentry, M. V. \& Meliska, C. J. Low body temperature in long-lived Ames dwarf mice at rest and during stress. Physiol. Behav. 67, 433-437 (1999).

22. Finkel, T. \& Holbrook, N. J. Oxidants, oxidative stress and the biology of ageing. Nature 408, 239-247 (2000).

23. Migliaccio, E. et al. The p66 $6^{\text {shc }}$ adaptor protein controls oxidative stress response and life span in mammals. Nature 402, 309-313 (1999). 
24. Sun, J. \& Tower, J. FLP recombinase-mediated induction of $\mathrm{Cu} / \mathrm{Zn}$-superoxide dismutase transgene expression can extend the life span of adult Drosophila melanogaster flies. Mol. Cell Biol. 19, 216-228 (1999).

25. Dupont, J., Karas, M. \& LeRoith, D. The potentiation of estrogen on insulin-like growth factor I action in MCF-7 human breast cancer cells includes cell cycle components. J. Biol. Chem. 275, 35893-35901 (2000).

26. Bartke, A., et al. Extending the lifespan of long-lived mice. Nature 414, 412 (2001).

27. Kulkarni, R. N. et al. $\beta$-cell specific deletion of the IGF-1 receptor leads to hyperinsulinemia and glucose intolerance but does not alter $\beta$-cell mass. Nat. Genet. 31, 111-115 (2002).

28. Clancy, D. J., Gems, D., Hafen, E., Leevers, S. J. \& Partridge, L. Dietary restriction in long-lived dwarf flies. Science 296, 319 (2002).

29. Honda, Y \& Honda, S. Oxidative stress and life span determination in the nematode Caenorhabditis elegans. Ann. N Y Acad. Sci. 959, 466-474 (2002).

30. Wolkow, C. A., Kimura, K. D., Lee, M. S. \& Ruvkun, G. Regulation of C. elegans life-span by insulinlike signaling in the nervous system. Science 290, 147-150 (2000).

Acknowledgements: We thank P. Monget for contributions to the experimental design, N. R. Holzenberger for assistance with metabolic and growth studies, G. Hamard for help with MEF, J. Sappa for language revision, F. Veinberg for blood biochemistry, and P. Casanovas and M.-C. Samson for animal care. MENRT sponsored this study with a grant to M.H. and Y.L.B. We thank D. LeRoith for support to J.D.

Correspondence and requests for materials should be addressed to M.H. (e-mail: holzenberger@st-antoine.inserm.fr)

\section{LEGENDS}


Figure 1 IGF-1R gene targeting, receptor expression, and growth phenotype. a, We flanked exon 3 of the wild-type (WT) IGF-1R gene with a neomycin resistance cassette $\left(n e o^{R}\right)$ and two loxP sites (triangles). Exon 3 and neo ${ }^{R}$ were then deleted by Cre-lox recombination, producing the IGF-1R (knockout) allele ${ }^{14,15}$. bp, base pairs. b, Allele-specific RT-PCR ${ }^{26}$ revealed that heterozygous IGF-1R ${ }^{+/-}$mice produced mRNA from wild-type $(+)$and knockout (-) alleles (double band in 2 and 3). M, DNA size marker. c, While IGF-1R levels were halved in IGF-1 $\mathrm{R}^{+/-}$animals (bar graph), the relative distributions (autoradiographic pattern) were unchanged. Receptors were undetectable in IGF-1R ${ }^{-/}$embryos (data not shown). Together, this indicated that the remaining, intact allele did not compensate for its inactivated homologue. Non-specific binding was $8 \%$; scale bar $=5 \mathrm{~mm}$. d, IGF-1R ${ }^{+/-}$and WT siblings showed identical growth until day 20. Thereafter, during the prepubertal growth spurt (weeks 3 to 5), slight deficits appeared. ${ }^{*} P<0.05$ (Mann-Whitney test).

Figure 2 Lifespan extension in IGF-1R ${ }^{+/-}$mice with respect to IGF-1 $\mathrm{R}^{+/-}$ (WT). a, IGF-1R ${ }^{+/-}$females (thick line) lived a mean of $33 \%$ longer than their WT littermates (756 \pm 46 vs. $568 \pm 49$ days, $P<0.01$, $t$-test). Kaplan-Meier analysis of survival revealed a later decline in IGF-1 $\mathrm{R}^{+/-}$mice compared to WT $(P<$ 0.001, Cox's test). b, IGF-1R ${ }^{+/-}$males lived $15.9 \%$ longer than WT littermates (679 \pm 80 vs. $585 \pm 69$ days, NS).

Figure 3 Glucose tolerance and energy metabolism in IGF-1R ${ }^{+/-}$mice. a, After intraperitoneal glucose injection, the glucose response was strongest in mutant males. Note that the significant sex-related dimorphism of the response observed in the WT is even more marked between mutants. ${ }^{* *} P<0.01$; ${ }^{* *} P<$ 0.001. b, Combining data from both sexes largely cancels out the male hyperglycaemic phenotype. ${ }^{*} P<0.05$; total $\mathrm{n}=89$. c, Metabolic rate (MR), 
measured by indirect calorimetry, did not differ between groups, whether we determined mean (24-hour), resting or basal MR ( $n=11-12$ per group).

Figure 4 Mutants showed normal fertility and were resistant to oxidative stress. a, Three-week mating resulted in similar proportion of pregnancies in mutant and WT females. These proportions declined from 5 to 13 months of age $\left(P<0.001, \chi^{2}\right.$ test). $\mathbf{b}$ While offspring decreased drastically with age, we found no consistent differences between IGF-1R ${ }^{+/-}$and control females. $\mathbf{c}$, Oestrus cycle length increases significantly with age $\left({ }^{\star \star \star} P<0.005\right)$, reflecting changes in the hormonal control of ovarian function, but we observed no differences between genotypes. $\mathbf{d}$, The interval between the first copulation plug (from a sterile male) and the next, indicative of ovarian capacity to maintain pseudogestation, decreased significantly with age in both groups. ${ }^{*} P<0.05$; ${ }^{* *} P$ $<0.02$; total $n=15$. e, Oxidative stress was induced by intraperitoneal paraquat injection (70 $\mathrm{mg} \mathrm{kg}^{-1}$ body weight). We checked the mice every two hours and censored the test at 72 hours. Kaplan-Meier analysis showed significantly more survivors among IGF-1 $\mathrm{R}^{+/-}$mice $(P<0.05$, Cox's test; $\mathrm{n}=67)$. When evaluated separately (inset), female mutants exhibited increased stress resistance $(P=$ 0.05 , Log-rank test; $n=37$ ), while the increase in males $(n=30)$ was small.

Figure 5 Lack of IGF-1R reduces activation of major intracellular signalling pathways in cultured mouse embryonic fibroblasts (MEF). We stimulated MEF with rhIGF-I (+) and analysed by Western blot. a, IGF-1R was reduced in IGF$1 \mathrm{R}^{+/}$and absent from IGF-1R $\mathrm{R}^{-/-}$MEF. $\mathbf{b}$, Anti-IGF-1R $\beta$, anti-IRS-1 and anti-p66 Shc immunoprecipitates (IP) were probed with anti-phosphotyrosine (anti-P-Tyr) antibodies. Phosphorylation of these proteins was reduced in ${ }^{+/}$and absent from $^{-1-}$ MEF. A phospho-Shc antibody revealed reduced activation of p52 Shc. 
c, d, IGF-I-induced association of Grb2 with IRS-1 or p52 Shc, and activation of ERK1/2 MAP kinases and Akt were also reduced in ${ }^{+-}$and absent from ${ }^{-/}$MEF. 
a IGF-1R gene targeting b RT-PCR
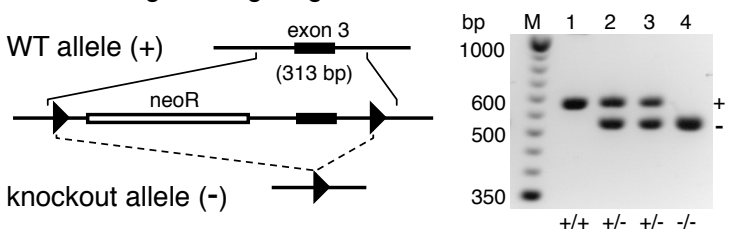

C Ligand binding assay and receptor autoradiography

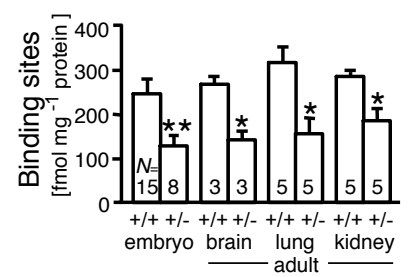

d Postnatal growth
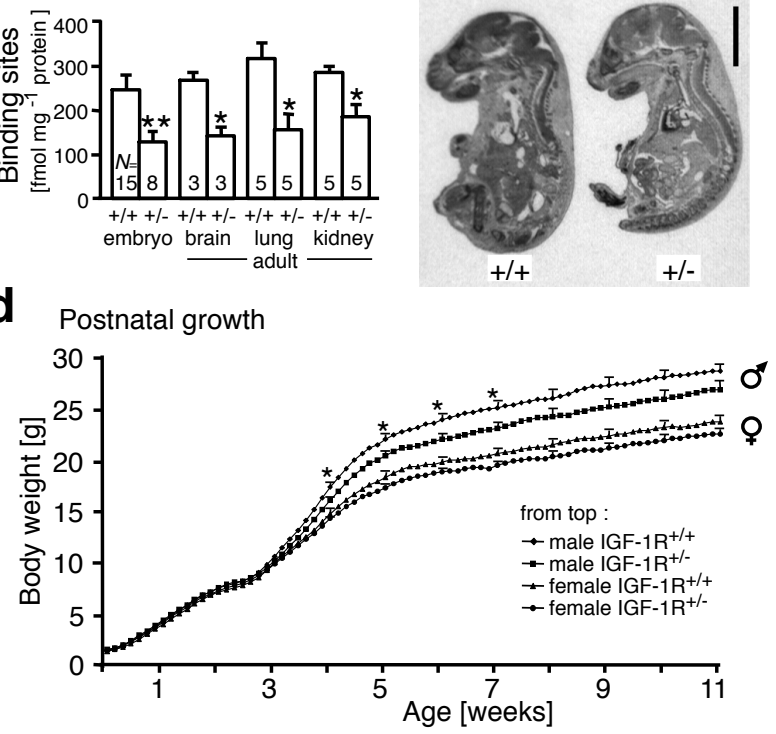

Fig. 1 
a Females

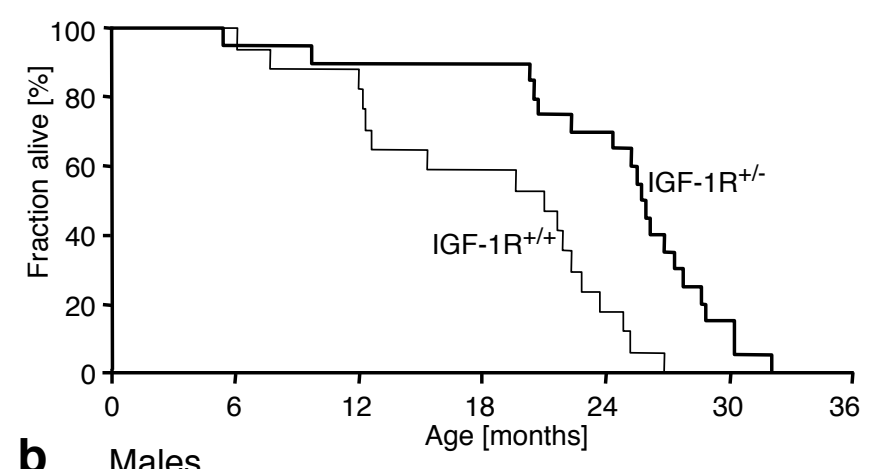

b Males

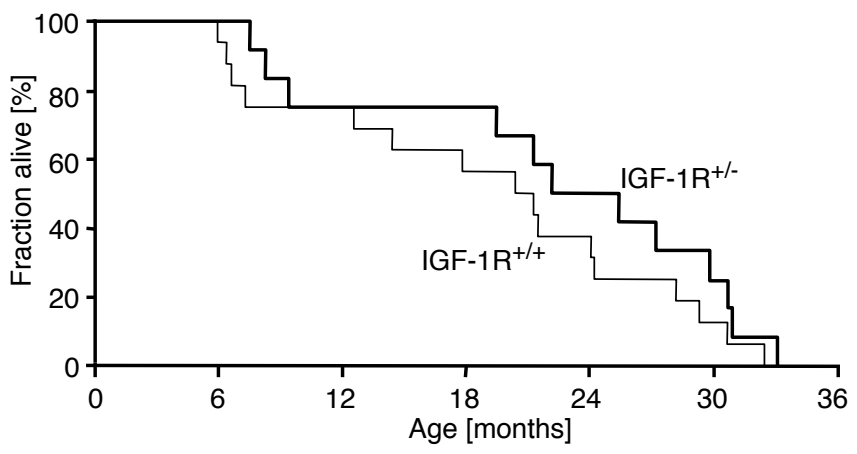

Fig. 2 

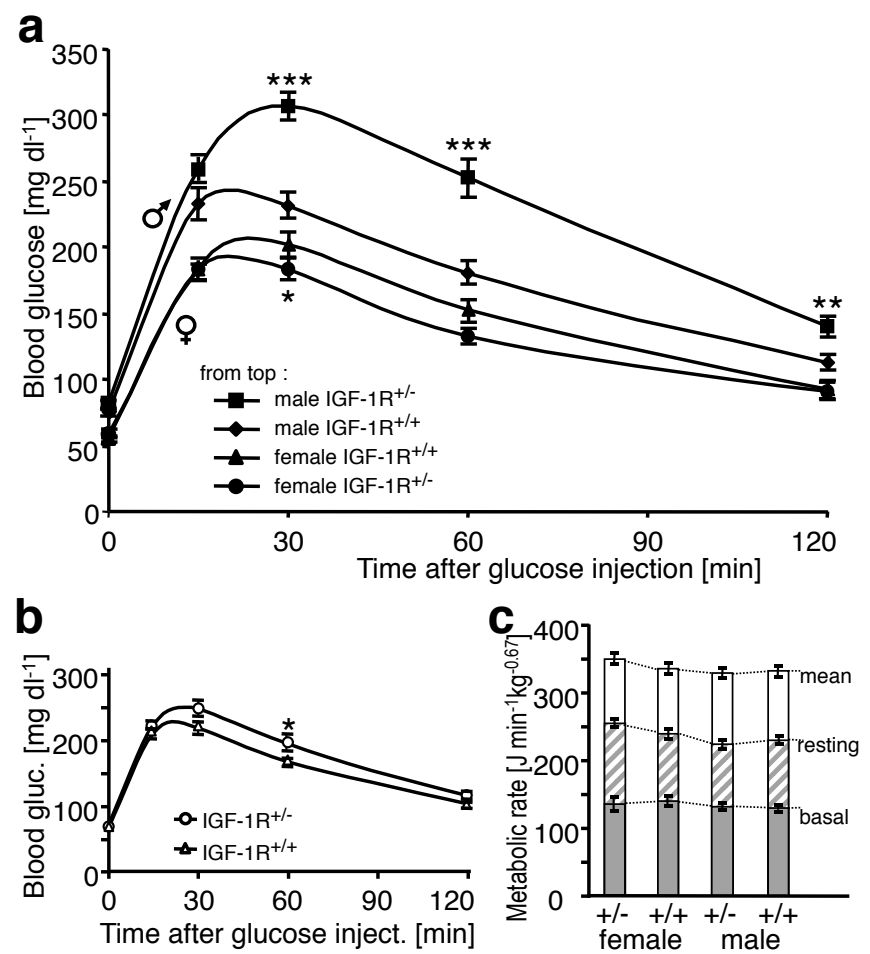

Fig. 3 
a

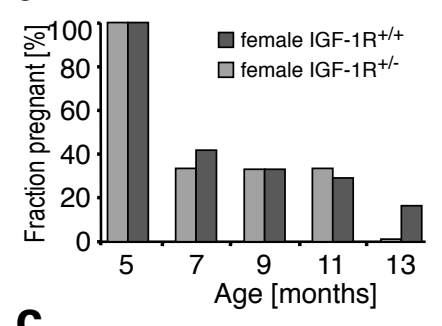

C

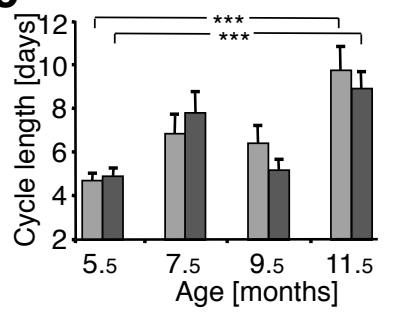

e

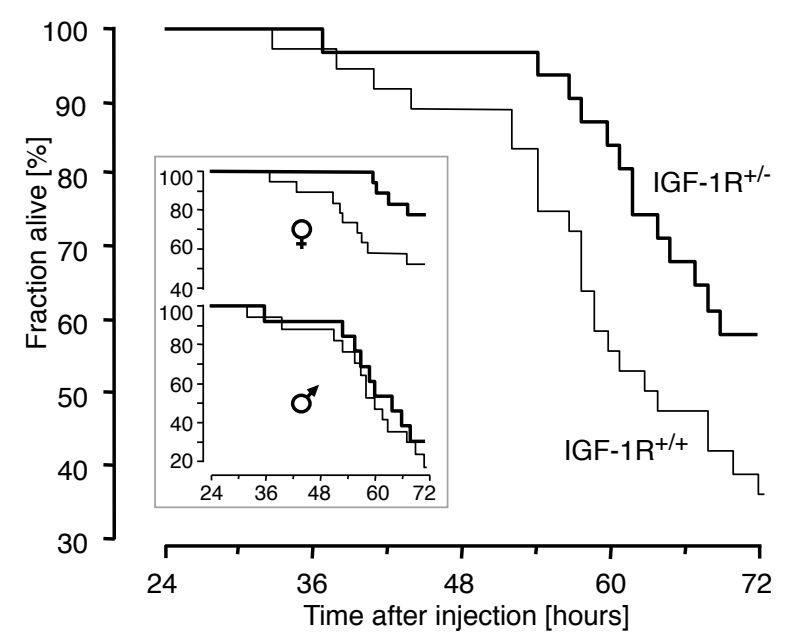

b

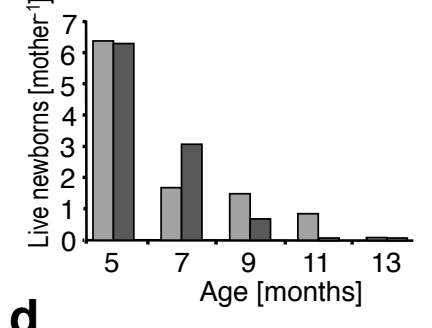

d

$\left.{ }^{5} 18\right] \square *$

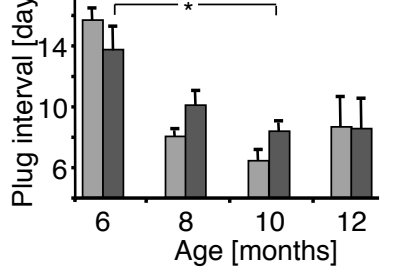

\section{2}

, 


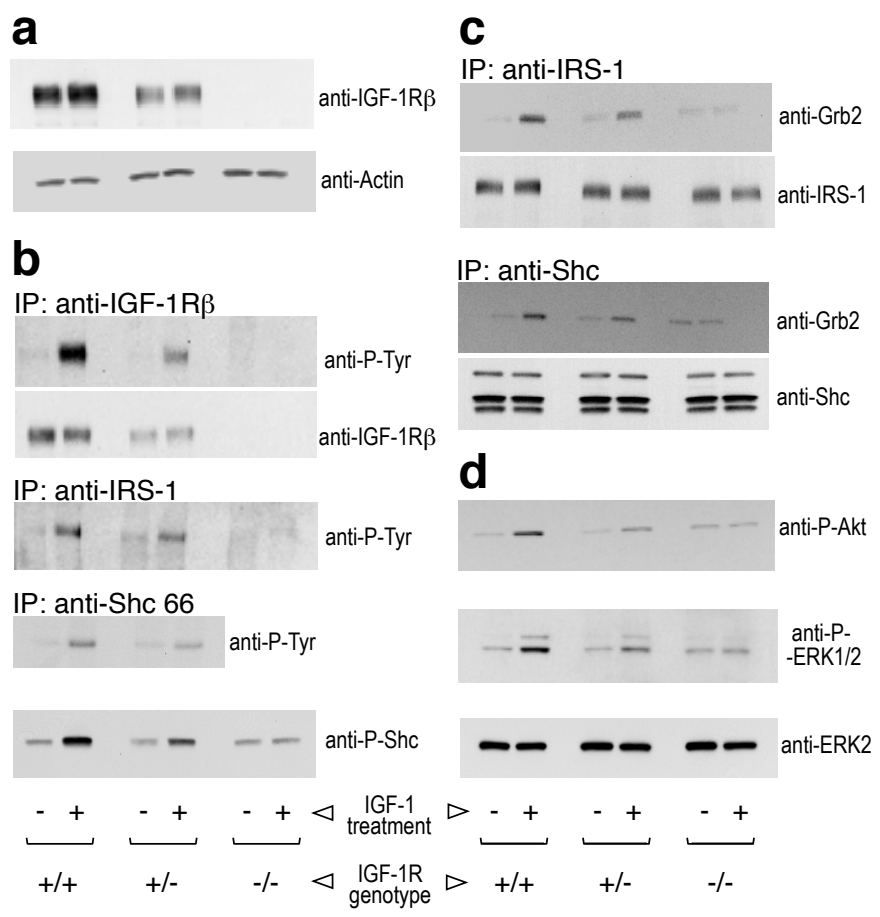

Fig. 5 
Supplementary Information

Methods

IGF-I receptor expression. Recombinant human IGF-I (rhIGF-I, for binding assays) and rhdes(1-3)IGF-I (for autoradiography) were labelled with ${ }^{125}$ I. The in vitro IGF-I ligand binding assay has been described in Holzenberger, M. et al. (2000) Endocrinology 141, 25572566 and in Holzenberger, M. et al. (2001) Endocrinology 142, 4469-4478. Crude membranes were prepared from day 19 embryos, and from adult brain, kidney and lung. The receptor affinity $\mathrm{Kd}$ determined from this assay (average $455 \mathrm{pM}$ ), did not differ significantly between IGF-1R ${ }^{+/-}$and wild-type mice. For receptor autoradiography, day 19 embryos were quickly frozen and stored at $-80^{\circ} \mathrm{C}$. Embryo sections $(16 \mu \mathrm{m})$ were incubated for $30 \mathrm{~min}$ in ice-cold PBS (pH 7.4), and incubated in $0.5 \mathrm{ml}$ of ice-cold $50 \mathrm{mM}$ Tris- $\mathrm{HCl}, 10 \mathrm{mM} \mathrm{MgCl} 2$ buffer (1 $\mathrm{mg} \mathrm{ml}^{-1} \mathrm{BSA}, 125 \mu \mathrm{g} / \mathrm{ml} \mathrm{NEM}, 250 \mu \mathrm{g} \mathrm{ml}^{-1}$ bacitracin, $100 \mathrm{KIU}$ aprotinin, $\mathrm{pH}$ 7.6) containing 20 pM [125I]rhdes(1-3)IGF-I. We measured non-specific binding with $0.2 \mu \mathrm{M}$ rhIGF-I. After incubation for $20-24$ hours at $4^{\circ} \mathrm{C}$, sections were rinsed in ice-cold $50 \mathrm{mM}$ Tris- $\mathrm{HCl}$, dipped in ice-cold distilled water, dried at room temperature, and placed against Biomax MR autoradiographic film.

Western blotting. Antibodies to ERK2 (C14), Grb2 (C23) and the B-subunit of IGF-1R (C20) were from Santa Cruz, those against actin (clone AC) from Sigma. Antibodies specific for Akt protein, Akt phosphorylated on $\mathrm{Ser}^{473}$, and ERK1/2 MAP kinase phosphorylated on $\mathrm{Thr}^{202} / \mathrm{Tyr}^{204}$ were from Cell Signaling, those to IRS-1, all isoforms of Shc, p66 Shc and Shc phosphorylated on $\mathrm{Tyr}^{317}$ were from Upstate Biotechnology. The antibody against protein phosphorylated on tyrosine residues (PY20) was from Transduction Laboratories. We confirmed equal loading for each immunoblot.

Indirect calorimetry. Metabolic rate was determined by indirect 24-hour calorimetry as described in Oudart, H., Malan, A., Maho, Y. \& Géloën A (2000) Day-night pattern of energy expenditure and body temperature in cachectic tumour bearing rats. Br. J. Cancer 83, $1055-$ 
1060. $\mathrm{O}_{2}$ and $\mathrm{CO}_{2}$ were measured in the exhaust gases from individual cages. A computer controlled the sequential analysis of four occupied cages and one unoccupied (reference) cage, repeating the cycle every $11 \mathrm{~min}$. Tubing was rinsed for $90 \mathrm{~s}$ and gases were then measured over $40 \mathrm{~s}$ (10 data points, one every $4 \mathrm{~s}$ ) before switching to the next cage. A mass flowmeter controlled constant flow (precision $<1 \%$ ). Air was dried with a permapure system with fresh calcium chloride, and entered a paramagnetic oxygen analyser, and an infrared carbon dioxide analyser (range: $0-1 \%$ ). For daily calibration, we used pure $\mathrm{N}_{2}$ and standards of $20.2 \% \mathrm{O}_{2}$ and $0.6 \% \mathrm{CO}_{2} . \mathrm{O}_{2}$ and $\mathrm{CO}_{2}$ differences between samples from reference and occupied cages multiplied by flow rate yielded the respiratory gas exchange. Mice were allowed to acclimatise to their metabolic cage for two days and measurements were made on the third day. We calculated energy expenditure from Depocas-Hart equations (Depocas, F. \& Hart, J. S. 1957 J. Appl. Physiol. 10, 388-392), corrected for body weight (BW; see: Heusner, A. A. 1985 Ann. Rev. Nutr. 5, 267-293) and expressed the result in $\mathrm{J} \mathrm{min}^{-1} \mathrm{~kg}^{-0.67} \mathrm{BW}$. 